\title{
JOB SATISFACTION AND PERFORMANCE: A SURVEY STUDY ON INTERNSHIP STUDENTS OF UNIVERSITAS NEGERI MALANG
}

\author{
Rosyidah $^{1 *}$, Utami Widiati ${ }^{1}$, Andika Agung Sutrisno ${ }^{1}$, Ary Fauzi ${ }^{1}$, Kukuh Prayitno Subagyo ${ }^{1}$, \\ Nurhidayati ${ }^{1}$ \\ ${ }^{1}$ Universitas Negeri Malang \\ Jl. Semarang No.5, Sumbersari, Lowokwaru, Kota Malang, Jawa Timur 65145, Indonesia
}

\begin{abstract}
This study aims to describe the satisfaction of host companies to internship students toward their competencies and performance and suggest improvements to the internship program. The research subjects were students who were undertaking internships in 64 institutions in Malang areas, both in the business and industrial world. Research data are obtained from questionnaires. The results showed that the qualifications of the internship students were in the range of good to very good. These findings are following the expectations of host companies, which also recognize that the competencies of internship students are in line with their expectations and needs. However, some students worked less efficiently, so host companies are not really satisfied. According to the host companies, three things need to be improved: (1) the duration of the internship, (2) monitoring, and (3) student readiness. Regarding the length of the internship, host companies suggest that the internship program's duration occupies at least three months. Host companies hope that the supervisors monitor all students who are apprenticed. Besides, the internship students should prepare in advance by giving them special provisions about the company's product knowledge and related hard skills and soft skills needed in the future jobs. These findings suggest the universities, faculties, students, host companies to develop both of the experiences and satisfaction as possible.
\end{abstract}

Keywords: satisfaction of host companies, internship students' performance, student competence

How to cite: Rosyidah, R., Widiati, U., Sutrisno, A., Fauzi, A., Subagyo, K., \& Nurhidayati, N. (2020). Job satisfaction and performance: A survey study on internship students of Universitas Negeri Malang. Jurnal Pendidikan Vokasi, 10(1), 93-102. doi:https://doi.org/10.21831/jpv.v10i1.29874

*Corresponding Author:

Rosyidah@rosyidah.fs@um.ac.id

- Department of German Literature, Faculty of Letters,

Universitas Negeri Malang

J1. Semarang No.5, Sumbersari, Lowokwaru, Kota

Malang, Jawa Timur 65145, Indonesia 


\section{INTRODUCTION}

One of the main challenges of a university is how to transfer knowledge and expertise to students to be accepted by the business world and industrial world or Dunia Usaha Dunia Industri (later called DUDI). For this reason, universities must be able to understand the market needs and accommodate them in programs in the curriculum. In other words, the university must adjust the knowledge transfer process to the demands and needs of the market so that there is no gap with DUDI. Universities must be able to build collaborations with DUDI in various sectors. One form of cooperation is in the way of an internship program.

An internship is a learning process to improve student skills outside the applicable education system, in a relatively short time, with methods that prioritize practice rather than theory (Sari, 2014). Meanwhile, McMahon and Quinn state that an internship is an educational program that provides work experience to students. For that, they must leave campus for a certain period, and they are closely monitored by experienced workers (McMahon \& Quinn, 1995). Furco defines an internship as a program that engages students in a job, primarily to provide them with hands-on experience that enhances their learning by understanding relevant problems in a particular field, the process of learning from an expert through real-world activities (Furco, 1996). Based on the three definitions above, it can be concluded that internships provide significant benefits for students because they can provide the experience that shapes students' personalities and has the professional expertise, quality, and able to develop along with their fields. Internships have an increasingly important role in education because they provide several benefits for students, including work experiences, job-related guidance, and networking with students from various other institutions where they carry out internships (Bukaliya, 2012). Meanwhile, according to Mgaya and Mbekomize, the internship program benefits not only for the students but also for the universities and the host companies (Mgaya \& Mbekomize, 2014).

Therefore, an internship program is compulsory in the curriculum of an undergraduate program in which the purpose is to prepare students to become professional human resources and ready for work. It is understandable since the internship is mostly giving experiences to exposure to real work. Internships also become very popular among employers, employees, and universities worldwide (Holyoak, 2013). For students, an internship is an opportunity to gain work-related experience and apply their knowledge in a professional work environment (Renganathan et al., 2012). Meanwhile, employers have stressed the importance of work experience in the recruitment process (D'Abate et al., 2009). Therefore, according to D'Abate et al., universities have to maintain the apprenticeship programs since it is needed to bridge the gap between the theory and practice.

The demand for internships is increasing because internships are believed to improve students' working skills and contribute to society. By the increasing demand for internships, universities must be able to prepare the readiness of students who carry out internships so that their performance during the internship can meet the partner institutions' expectations. These performances refer to the quality improvement of the students' hard skills and soft skills.

The implementation of an internship program in the Faculty of Letter or Fakultas Sastra (later called FS) Universitas Negeri Malang (later called UM) is integrated into the PKL-(Work Practice) course with a load of 4 credits. By doing the internship program, the students are likely to deepen their understanding of the theoretical knowledge and its practical application in the field; the internship students will also learn about their communities and real work situations. These experiences allow them to build the professional networks and partnerships which needed. For this purpose, FS UM cooperates with agencies, both private DUDI and the government institutions. The host institutions give the students practical skills during the internship program for about 1-2 months to build the intensive interaction between students and the host institutions.

The internship program is one of the compulsory courses in FS UM. The internship activities include the preparation and training, the implementation, and the monitoring and evaluation of the internship implementation. This activity is expected to be able to establish students' professional competencies. For the internship program's sustainability, the departments/study programs need to carry out monitoring and evaluation sessions regularly. At the end of the internship program, the advisor lecturers do a monitor and evaluation session. The lecturers monitor and evaluate the in- 
ternship students' progress by using the assessment sheets developed by each study program/ department. The purpose of doing this is because the lecturer can find solutions if there are problems in the implementation of the internship. The lecturer asks the students about the attendance, the internship plan, questions, and general impression of the internship. However, this monitoring and evaluation session of the internship program does not involve host institutions. Furthermore, to provide more objective results of the internship program, host institutions/ companies should share information related to internship students' performance. It means that the monitoring and evaluation session needs to involve the host organization's satisfaction indicators.

Satisfaction can be interpreted as feeling happy or disappointed in someone as a result of the comparison between the performance that is shown and the expectation. In the context of this study, satisfaction is a condition when the needs, desires, and expectations of DUDI as the host organization can be met through the performance of students who carry out an internship. The research on the internship program's satisfaction aims to obtain information about the quality and performance of the internship program seen from the host institutions' point of view, whether the performance has been as expected.

Research on DUDI's satisfaction with student internships' performance has indeed been carried out, including a study conducted by Sari, involving government agencies (Sari, 2014). Meanwhile, Widyastuti and Fattah's research was conducted by the ITS research team, and the research subjects were ITS graduates in 2016, involving DUDI (Widyastuti \& Fattah, 2016).

However, similar research for students at FS UM has never been done. Based on those aforementioned references, this study differs from previous research, although it also studied user satisfaction internship problems. The subject of this research is students who are conducting an apprentice 2019 from the Department of English, Department of Indonesian, Department of German, and Department of Art and Design, who did an internship on DUDI.

\section{RESEARCH METHOD}

This research employs a descriptive study with a qualitative approach that aims to describe student internships' performance and find out things that need to be improved in the student internship program. This research data were in the form of DUDI's opinion/statement about their satisfaction with the performance of internship students and was obtained through human instruments with supporting instruments in the form of qualitative questionnaires (Eckerdal \& Hagström, 2016). The research's focus is two types of research data, namely (1) performance data of internship students and (2) data on things that need to be improved in student internship programs. The researchers analyzed the data findings by following the steps of qualitative data analysis: data reduction, data display, conclusion, and verification (Sugiyono, 2011).

\section{RESULTS AND DISCUSSION}

\section{Internship Performance}

Performance is a result of work achieved by a person in carrying out the tasks assigned following a predetermined time and goals or objectives that have been set (Sianturi \& Mulyadi, 2019). The data analysis results show that some of the internship partner institutions infer that the internship students' performance is already good and excellent. The internship students had developed their abilities, skills, personality performance, and professional performance.

\section{Quality of Work}

The quality of performance is the quality that must be done (good or bad). If it is measured qualitatively, it reflects the "level of satisfaction," namely how good the results are. The quality performance of an employee, including the performance of interns students, is one of the factors that influence the company's success in achieving its goals. If the quality of employee performance is low, the company could not achieve the specified target. Table 1 presents an example of company statements that the variety of student internships is both good and very good. 
96 - Rosyidah, Utami Widiati, Andika Agung Sutrisno, Ary Fauzi, Kukuh Priyatno Subagyo, \& Nurhidayati

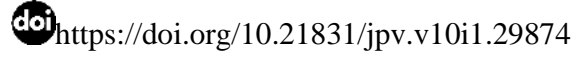

Table 1. Quality of Work with the Predicate 'Good'

\begin{tabular}{ccc}
\hline No & Host Company & Comment \\
\hline 1. & Terakota.id & The performance of students is already good, as expected \\
2. & Kapanlagi.com & The work is good, and it fulfills the expectations \\
3. & Kusuma Satria & The result is satisfied \\
4. & Air Asia Travel Service & The work result of the interns' students here is good \\
\hline
\end{tabular}

Table 1 shows the four examples, and it explicitly states that the internship students' performance is good. This shows that DUDI is satisfied with the performance of students. Meanwhile, there were also very good results, as shown in the examples in Table 2.

Table 2. Quality of Work with the Predicate 'Excellent'

\begin{tabular}{lcc}
\hline No & Host Company & Comment \\
\hline 1. & Radio Elfara & Because it is matched with the field, Firda'swork is very good \\
2. & PT Malang Intermedia & Their supporting design isvery good \\
3. & ORKHA & Their works are excellent \\
4. & Tugu Hotel Malang & The interns' students' work is impressive \\
\hline
\end{tabular}

As seen in Table 2, it can be inferred that DUDI, who also stated explicitly that the work of interns students from the FS UM was very good, and they are very satisfied with their performance. It can be inferred, the good/very good performance of the interns' students is beneficial for them when they enter the world of work in the future (Lima et al., 2014). Based on the description, it can be concluded that the internships student's quality work is in the range of good and very good. The quality of the work is in line with DUDI's expectations.

\section{Work Efficiency}

Work efficiency refers to the definition of work efficiency provided by the Indonesian online dictionary, that is the ability to carry out tasks adequately and appropriately without wasting time, energy, costs, and carrying out work in specific ways without reducing predetermined goals (Raziq \& Maulabakhsh, 2015). The data analysis results show that there were a small number of students who work less efficiently. The statements of DUDI related to this efficiency are shown in Table 3.

Table 3. Work Efficiency

\begin{tabular}{ccc}
\hline No & Host Company & Comment \\
\hline 1. & PT Malang Intermedia & Internship students must be responsive to work and discipline \\
2. & IRDH CV & Students must use efficient methods at work \\
3. & Terakota.id & Students must be competent, creative, and discipline \\
\hline
\end{tabular}

Table 3 reveals that some students who did the internship at the host companies work inefficiently. The words or phrases responsive, discipline, capable, and creative are words/phrases that are commonly used to describe the way or procedures of an employee's work. An employee is expected to complete the work within a limited time, and it indicates that the employee not only needs to increase the speed of the work but also needs to keep the quality of the work (Raziq \& Maulabakhsh, 2015). Therefore, inefficient internship students lack time to complete their work, while efficient internship students feel that they lack the task to spend their time.

Based on those descriptions, it can be concluded that there were a small number of internship students who work less efficiently. This is not in line with DUDI's expectations.

\section{Job Competence}

The work competency is the workability of a person that includes the aspects of knowledge, skills, and work attitudes that are following the standards set (Sumendap et al., 2015) and Law of Republic of Indonesia No. 13 of 2003 on Manpower. Regarding work competence, most companies stated that internship students from FS UM had mastered the task material they had to do. Table 4 shows some examples of DUDI statements in this regard. 
97 - Rosyidah, Utami Widiati, Andika Agung Sutrisno, Ary Fauzi, Kukuh Priyatno Subagyo, \& Nurhidayati

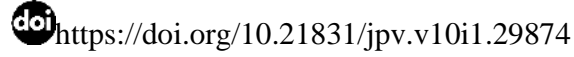

Table 4. Work Competencies

\begin{tabular}{ccc}
\hline No & Host Company & Comment \\
\hline 1. & ORKHA & Student interns help to run the company's processes \\
2. & Wisma Jerman & The mastery of the material is good \\
3. & Translationlinker & The basic and theoretical knowledge are good \\
4. & PT Malang Intermedia & Their knowledge is good and its applicable here \\
5. & Radio Elfara & Field-controlled and used here \\
\hline
\end{tabular}

Based on Table 4, the competence of internship students is good. Besides, DUDI also stated that they needed these work competencies. The work competence for employers, among others, is to improve the efficiency and the effectiveness in the industry, to increase business competition in the industrial world, and as a predictor of employee's job success. Employees who are professional and have competencies can handle problems and varied range of the issues related to different fields of knowledge and develop them (Lima et al., 2014). For students who do internships, competencies are determinants of their success in getting a job and pursuing a career soon after they graduate.

Some host institutions are satisfied with the competence of the internship students. As stated in the definition, satisfaction refers to feeling happy or disappointed because someone's expectations of something are fulfilled or not. In the context of this study, the achievement is related to the feelings of pleasure or disappointment that is experienced and felt by DUDI on the performance of the internship students after comparing the results of the internship performance with their expectations.

The results show that DUDI is satisfied with the internship students in the 2018/2019 academic year. In this case, DUDI's satisfaction with the internship students' performance can be seen from the general statements given by DUDI related to their experience guiding the students. The experience of supervising interns from the faculty level impressive for all DUDI institutions involved. It means the performance of the internship raises a positive feeling or gives a good impression to DUDI. The tracing of student appraisal documents shows that generally, DUDI has a good impact on the discipline, initiative, accuracy, and cooperation demonstrated by the students. For these four aspects, the majority of students received an average grade of 90 or in a category of excellent.

In other words, during internships at the host companies, the performances of students, whereby performance standards, work procedures, code of ethics, and generally applicable organizational regulations. Thus, it can be concluded that the results of the internship students have shown conformity with the expectations of DUDI.

\section{Suggestions}

The results show that although the internship students were considered good, there were essential things that had to be corrected immediately by policymakers at the university level. The things that need to be improved from the program are the duration of the internship, the internship's monitoring, and the readiness of the students to take part in the internship. In details, these three things are explained in as follows.

\section{Internship Duration}

The students carry out apprenticeship programs in various DUDI institutions, which are partners for four weeks. According to most partner institutions, the duration of the internship is inadequate and needs to be extended. Table 5 shows the examples of data related to the need to increase the length of the internship.

Table 5. Apprenticeship Duration

\begin{tabular}{ccc}
\hline No & Host Company & Comment \\
\hline 1. & Hi Animation & Add the minimum duration of the internship program \\
2. & PT Aice Ice Cream & Extend the internship time \\
3. & Wisma Jerman & The duration of the internship should be extended \\
\hline
\end{tabular}


Table 5 points to the fact that the duration of the student internship, which is four weeks, is not ideal for DUDI. According to Bukaliya, the perfect length of an internship is six months, because in general, people work long-term to learn skills, gain valuable experience, or to pursue a career seriously (Bukaliya, 2012). Meanwhile, in several universities, both in the domestic area and abroad, student internships' duration varies between one to six months. For example, at Universitas Padjadjaran Bandung, students carry out internships at SOEs for six months, while at Universitas Indonesia Jakarta, students can carry out internships for at least one month. Abroad, as in Germany, students generally carry out compulsory internships/practical work for five to six months, while the duration of internships that are not mandatory is at least six months, and some are even seven months (Seitter, 2009). With the length of the internship, students can learn and gain experience in their chosen field. Within the internship's ideal duration, the apprentice can make a good decision, whether to continue working in the industry or do other things that might be more suitable. In other words, if the apprenticeship time is less than ideal, it is feared that students will not be able to learn many things in depth even if they work every day, gain less valuable experience, and subsequently make wrong decisions for their future.

The internship duration, especially at the tertiary level, can be adjusted to the schedule of student academic activities (Briel \& Getzel, 2001). For this reason, the internship program, including the duration of the internship, can be designed and prepared according to the academic calendar at the relevant tertiary institution. However, the ideal period of apprenticeship is a period that allows interns to complete worthwhile projects for intern students and employers. It must also be able to bring students into the rhythm of the work, creating a more realistic experience. For this reason, an internship duration of three to four months with 20-35 hours per week is considered ideal.

\section{Internship Monitoring}

Internship monitoring is part of the internship program that faculty must carry out to monitor all students who are conducting internships in various host agencies. Through internship monitoring, communication is expected to occur regarding issues related to apprenticeship between FS UM with the interns' students and with the host institutions. The FS usually monitors internship activities by sending lecturers and collaborating with internship instructors/supervisors from DUDI.

The results showed that this did not work as it should be. Some DUDI institutions state directly and indirectly that the FS lecturer did not monitor some interns' students at their location. This means that FS has no lecturers to monitor the implementation of internships in several locations during the internship program. Table 6 shows an example of a statement from DUDI's institution regarding matters that must be improved.

Table 6. Internship Monitoring

\begin{tabular}{ccc}
\hline No & Host Company & Comment \\
\hline 1. & Terakota.id & Need control from the campus for students' activity directly \\
2. & IRDH CV & There must be a lecturer visit \\
3. & ORKHA & There must be a regular monitoring \\
4. & MTIC & PKL lecturers must visit \\
5. & 24 Slides & Lecturers supervisor should have the time to pay a visit to the host company \\
\hline
\end{tabular}

Table 6 reveals that the internship students in these host companies did not receive a monitoring visit from the supervisor. Monitoring should be carried out by the lecturers periodically during the internship program. With regular monitoring activities, it is expected that the supervisor can help to find solutions for all the difficulties and problems experienced by the student participants. However, monitoring can be carried out by the supervisor at least once during the internship program. Control can be done indirectly through electronic media (Juradin, 2018). However, direct monitoring is still considered more effective because by making visits to the internship, the lecturers can see the activities and problems of the students directly, communicate and find solutions with the mentor/instructor intern from the host companies. By monitoring, internships can provide professional and precious work experience for students (Kramer-Simpson, 2018). 
99 - Rosyidah, Utami Widiati, Andika Agung Sutrisno, Ary Fauzi, Kukuh Priyatno Subagyo, \& Nurhidayati

dointtps://doi.org/10.21831/jpv.v10i1.29874

\section{Students' Readiness}

In this study, students' readiness refers to the willingness to carry out the internships program. It is essential to have readiness as a reference for graduation in this program. Besides, in the era of technology and globalization, DUDI requires its workforce to have high abilities and strong personalities. Students as prospective workers need to have the readiness to meet the DUDI's demands. Thus, work readiness is very beneficial for every student who is an internship and also profitable for DUDI institutions. However, each student has a different level of work readiness.

In general, students' readiness to carry out an internship program is the overall condition of students who make themselves ready to enter the workforce. Thus, internship students should be able to carry out certain activities concerning work. Agusta (2014) states that work readiness is the capacity of a person to improve his workability consisting of science and expertise and attitudes. Based on this description, students' readiness for internships must include the willingness of science, the readiness of expertise, and the readiness for attitude. The results show that according to some DUDI institutions, some FS students are not ready for work, still need to be prepared as well as possible before carrying out an internship. Table 7 shows examples of statements from DUDI institutions leaders regarding the work readiness of FS UM students currently doing an internship.

Table 7. Student Readiness

\begin{tabular}{ccc}
\hline No & Host Company & Comment \\
\hline 1. & Translationlinker & Need more prepared briefing and more practical \\
2. & PT. Malang Intermedia & Internship students must understand the product knowledge of \\
the company \\
3. & Terakota.id & Equipping students with soft-skills that are suitable with \\
& the industry world \\
\hline
\end{tabular}

Based on Table 7, the work readiness of FS UM students is considered to be lacking in terms of knowing practical abilities, understanding the company's product knowledge, and mastering soft skills. Practical skills are usually called hard skills, the primary skills needed in a job, including science, technology, and technical skills related to the field of science (Pentingnya "hardskill" dan "softskill" dalam dunia karir, 2018). Meanwhile, non-technical abilities are known as soft skills, the abilities or qualifications to deal with others and themselves. Thus, soft skills encompass interpersonal skills, personal skills and refer to values, motivation, behavior, character, habits, and attitudes. Abilities and skills needed by companies are not only in the form of hard skills but also soft skills. This was also conveyed by Rahayu and Anna (2013) that the criteria for quality human resources can be seen from the balance between soft skills and hard skills. Hard skills refer to academic skills, science, and technology. Meanwhile, soft skills are skills that refer to things non-academic and non-technical, intrapersonal, and interpersonal. Soft skills can be seen, among others, from the way a person designs his future, his motivation, building his confidence, his way of communicating, his character, and his leadership. According to Al Abduwani (2012), a combination of hard skills and soft skills possessed by an employee, including an intern is very necessary in the world of work. The soft skills can help an employee to get along quickly in the work environment because honesty, a sense of responsibility, discipline, self-confidence that a person has naturally makes it easy for the person to be accepted into the work environment. Indirectly, soft skills can also help the person develop hard skills they have; for example, people with strong motivation to achieve an ideal strive to master various hard skills as demanded.

Understanding of product knowledge is the understanding of consumers about a product that can influence purchasing decisions (Indriani \& Suharyono, 2017). This is an essential requirement in business to compete and gain customer satisfaction. The skill of understanding the company's product knowledge is a must for every employee, including the intern students. Lack of knowledge of the company's product marketing strategy is one aspect of poor service. In other words, internship students who lack knowledge about the strengths or the weaknesses of the company's products cannot provide the best service. The company's customers also feel that the student is incompetent because they cannot offer the best solutions and appropriate suggestions for the customers in using company products. 
The internship students who lack work readiness seem not to understand what to do and what tasks they need to complete immediately. This situation makes the intern students look passive, less responsive, and not proactive in the internship activities. This can affect the performance of the students when they enter the real world of work. Thus, students' work readiness needs to be possessed as early as possible and before coming into the real world of work. It is also to ease the burden of DUDI in establishing human resources. Work readiness means the ability, skills, and work attitudes that are appropriate to the demands of the community/DUDI and following the potential possessed by students in various types of specific jobs that can be directly applied.

\section{CONCLUSION}

Based on the focus results of the study, two conclusions are presented. First, in general, DUDI is satisfied with FS UM students' performance who join the internship program in the 2018/ 2019 academic year. During the internships program, the host institutions gave the comment on the quality of work of FS UM student internships wherein the range of predicate good and excellent. This is following DUDI's expectations, which also recognizes that the work competency of internship students from FS UM is in line with expectations, and the DUDI requires those work competencies. However, some intern students work less efficiently, so DUDI is not satisfied with this.

Second, to improve the internship program of FS UM students, there are three things that are needed to be improved, namely the length of the internship, monitoring and evaluating session, and work readiness of students. Regarding the length of the internship, DUDI hopes that the internship duration of at least three months can be fulfilled by the FS UM. DUDI also hopes that FS UM monitors all students who are apprenticed through the visit of their supervisor. In addition, interns need to be prepared in advance with a special briefing; for example, given on product knowledge of the company, the things that are closely related to the hard skills and soft skills needed for jobs.

\section{ACKNOWLEDGMENT}

The authors express their profound gratitude to the Faculty of Letters and Lembaga Penelitian dan Pengabdian kepada Masyarakat (LP2M) Universitas Negeri Malang for funding this research under Grant 5.8/UN32.14/KP/2019.

\section{REFERENCES}

Agusta, Y. N. (2014). Hubungan antara orientasi masa depan dan daya juang terhadap kesiapan kerja pada mahasiswa tingkat akhir Fakultas Ilmu Sosial dan Ilmu Politik di Universitas Mulawarman. PSIKOBORNEO: Jurnal Ilmiah Psikologi, 2(3), 133-140. http://e-journals. unmul.ac.id/index.php/psikoneo/article/view/3653

Al Abduwani, T. A. R. (2012). The value and development of soft skills: The case for Sultanate of Oman. LAP - LAMBERT Academic Publishing.

Briel, L., \& Getzel, E. (2001). Internships in higher education: Promoting success for students with disabilities. Disability Studies Quarterly, 21(1). https://doi.org/10.18061/dsq.v21i1.254

Bukaliya, R. (2012). The potential benefits and challenges of internship programmes in an ODL institution: A case for the Zimbabwe Open University. International Journal on New Trends in Education and Their Implications, 3(1), 118-133.

D’Abate, C. P., Youndt, M. A., \& Wenzel, K. E. (2009). Making the most of an internship: An empirical study of internship satisfaction. Academy of Management Learning \& Education, 8(4), 527-539. https://doi.org/10.5465/AMLE.2009.47785471

Eckerdal, J. R., \& Hagström, C. (2016). Qualitative questionnaires as a method for information studies research. Proceedings of the Ninth International Conference on Conceptions of Library and Information Science. http://informationr.net/ir/22-1/colis/colis1639.html 
101 - Rosyidah, Utami Widiati, Andika Agung Sutrisno, Ary Fauzi, Kukuh Priyatno Subagyo, \& Nurhidayati

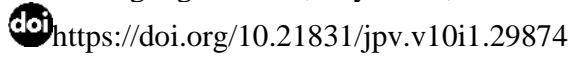

Furco, A. (1996). Service-learning and school-to-work: Making the connections. Service Learning, General, 32(1), 7-14.

Holyoak, L. (2013). Are all internships beneficial learning experiences? An exploratory study. Education + Training, 55(6), 573-583. https://doi.org/10.1108/ET-02-2012-0024

Indriani, R. S., \& Suharyono, S. (2017). Program Product Knowledge sebagai strategi pemasaran dan pengaruhnya terhadap penjualan (Studi kasus produk S-Tee PT. Sinar Sosro kantor penjualan wilayah Jawa Timur). Jurnal Administrasi Bisnis, 47(2), 187-192. http:// administrasibisnis.studentjournal.ub.ac.id/index.php/jab/article/view/1858

Juradin, J. (2018). Sistem informasi monitoring praktek kerja industri berbasis web. Undergraduate thesis. Universitas Negeri Makassar, Makassar.

Kramer-Simpson, E. (2018). Moving from student to professional: Industry mentors and academic internship coordinators supporting intern learning in the workplace. Journal of Technical Writing and Communication, 48(1), 81-103. https://doi.org/10.1177/0047281616646753

Law of Republic of Indonesia No. 13 of 2003 on Manpower, (2003).

Lima, R. M., Mesquita, D., \& Flores, M. A. (2014). Project approaches in interaction with industry for the development of professional competences. In Y. Guan \& H. Liao (Eds.), Proceedings of the 2014 Industrial and Systems Engineering Research Conference (ISERC 2014) (pp. 1668-1677).

McMahon, U., \& Quinn, U. (1995). Maximizing the hospitality management student work placement experience: A case study. Education + Training, 37(4), 13-17. https://doi.org/ $10.1108 / 00400919510088870$

Mgaya, K., \& Mbekomize, C. (2014). Benefits to host organizations from participating in internship programs in Botswana. Asia-Pacific Journal of Cooperative Education, 15(2), $129-144$.

Pentingnya "hardskill" dan "softskill" dalam dunia karir. (2018). Kompasiana.Com. https://www. kompasiana.com/jonithunder/5bf23690ab12ae448c353bb4/pentingnya-hardskill-dan-soft skill-dalam-dunia-karir

Rahayu, S., \& Anna, Y. D. (2013). Soft skills attribute analysis in accounting degree for banking. International Journal of Business, Economics and Law, 2(1), 115-120. http://ijbel.com/wpcontent/uploads/2014/06/Soft-Skills-Attribute-Analysis-In-Accounting-Degree-For-Banking -Sri-Rahayu-Yane-Devi-Anna.pdf

Raziq, A., \& Maulabakhsh, R. (2015). Impact of working environment on job satisfaction. Procedia Economics and Finance, 23, 717-725. https://doi.org/10.1016/S2212-5671(15) 00524-9

Renganathan, S., Ambri Bin Abdul Karim, Z., \& Su Li, C. (2012). Students' perception of industrial internship programme. Education + Training, 54(2/3), 180-191. https://doi.org/ $10.1108 / 00400911211210288$

Sari, B. L. (2014). Studi kepuasan pengguna magang mahasiswa Pendidikan Ekonomi bkk Pendidikan Administrasi Perkantoran Fakultas Keguruan dan Ilmu Pendidikan Universitas Sebelas Maret tahun 2014 [Undergraduate thesis. Universitas Sebelas Maret]. https://digilib. uns.ac.id/dokumen/detail/41906/Studi-Kepuasan-Pengguna-Magang-Mahasiswa-Pendidikan -Ekonomi-Bkk-Pendidikan-Administrasi-Perkantoran-Fakultas-Keguruan-Dan-Ilmu-Pendi dikan-Universitas-Sebelas-Maret-Tahun-2014

Seitter, W. (2009). Professionalitätsentwicklung in der weiterbildung (W. Seitter (Ed.)). VS Verlag für Sozialwissenschaften. https://doi.org/10.1007/978-3-531-91765-8 
102 - Rosyidah, Utami Widiati, Andika Agung Sutrisno, Ary Fauzi, Kukuh Priyatno Subagyo, \& Nurhidayati

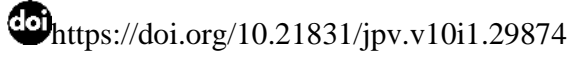

Sianturi, P. F. R., \& Mulyadi, H. (2019). Pengaruh pelatihan dan motivasi kerja terhadap kinerja karyawan pada karyawan divisi produksi PT Indo-Extrusions-Cimahi. Journal of Business Management Education (JBME), 2(2), 259-268. https://doi.org/10.17509/jbme.v2i2.2295

Sugiyono, S. (2011). Metode penelitian pendidikan pendekatan kuantitatif, kualitatif, dan $R \& D$. Alfabeta.

Sumendap, J., Mandey, J., \& Mambo, R. (2015). Pentingnya kompetensi kerja dalam meningkatkan kinerja Pegawai Negeri Sipil di Biro Umum dan Keuangan Universitas Sam Ratulangi Manado. Jurnal Administrasi Publik, 4(32). https://ejournal.unsrat.ac.id/index.php/ $\mathrm{JAP} /$ article/view/9900

Widyastuti, W., \& Fattah, A. H. (2016). Laporan survey kepuasan pengguna lulusan ITS tahun 2016. Institut Teknologi Sepuluh Nopember. 